\title{
Human Capital Reporting Practices of German and American Companies
}

Michaela Bednárová. University of Huelva. Spain. bednarova.mich@gmail.com

Roman Klimko. University of Economics in Bratislava. Slovakia. roman.klimko@euba.sk

Patrik Klimko. University of Economics in Bratislava. Slovakia. patrik.klimko@euba.sk

\begin{abstract}
Communication of social dimensions of the company plays a key role in the sustainable development of organizations. The aim of this empirical study is to analyze the extent to which German and American companies report on human capital indicators via their websites and the factors that can influence them. A content analysis of the annual sustainability reports of 60 companies listed in the DAX 30 and in the Fortune 500 (top 30 companies) was conducted. Our findings show that Europe`s leading position in sustainability reporting is undeniable, and on the other hand, online disclosure on human capital in the USA is still scarce and in its early stages. The factors influencing it are: sector in which the company operates and country where the company is headquartered. They also show that indicators such as number of employees, gender diversity of employees, and gender diversity of top employees are widely reported, while other indicators such as absenteeism, accidents and diseases at workplace, job stability and seniority are not used to a high extent.
\end{abstract}

Keywords: Human Capital Reporting, Sustainability, CSR, Legitimacy theory 


\section{INTRODUCTION}

Sustainability reporting has been the subject of increased attention from the business as well as the academic community. We are currently witnessing a shift in the reporting practices, as sustainability reporting is becoming standard among large corporations worldwide. King (IR, 2011) claims that we are entering a new era in corporate reporting in which the old form of annual report focusing primarily on financial information and short-term horizons is no longer adequate to meet the information needs of investors and other stakeholders. There is a demand for greater transparency regarding what the company is doing and why in order to enable stakeholders to gain a complete understanding of a company`s performance. Such a transparency requires different social and environmental disclosure besides the financial report.

The purpose of this paper is to explore to what extent do companies listed in the DAX 30 and in the Fortune 500 (top 30 companies) report on human capital indicators online (considering annual and sustainability reports available on their websites). Johnston (2001) claims that the relationship between a company and its human capital can be considered a precondition for the corporate social responsibility of that company as a whole. This assumption is based on the argument that if a company applies a high level of responsibility to its relations with employees, it is likely to do so to its relations with customers, as well as to the social and natural environment in which it operates.

Among the main reasons to report on non-financial information are an increased percentage of a company`s intangible assets and striving for sustainable development. Studies carried out to explore the market value by asset type of S\&P 500 companies show that between 1982 and 2009, the amount of intangible assets increased from $38 \%$ to $84 \%$ (IR 2011). As an increasing percentage of a company's assets are intangible, there is currently an increased need to report on nonfinancial information which is not shown on the balance sheet, in order to make more accurate projections of a company's future performance (Eccles and Krzus, 2010).

Although the reporting on intangible assets such as human capital is not compulsory in most of the countries (OECD, 2006) there is a number of different groups of stakeholders that are demanding its disclosure (e.g. AICPA, 1994; 
FASB, 2001). In November 2000, a European-level business campaign regarding CSR was launched with the aim to encourage European companies to report on CSR, inviting all publicly operating companies with more than 500 employees to adopt a triple bottom line approach (representing the reporting on financial, environmental and social impacts of the organization) in their annual reports (EBNSC, 2000). Regarding the current EU regulation on non-financial disclosure, on 29 September 2014 the EU Council adopted a new Directive concerning the CSR disclosure by large companies and groups, which amends the previously adopted Directive 2013/34/EU on the annual financial statements, consolidated financial statements and related reports of certain types of companies. It is giving the Member States two years thereafter to transpose it into national legislation. Accordingly, security market regulators in Canada and the United States were also mandating companies to extend their performance disclosure, reporting on nonfinancial information in order to gain public trust (Cormier, 2009). Moreover, the existence of investment rating systems such as the Dow Jones Sustainability Index and investment policy disclosure requirements have also caused increased pressure on companies to make these kinds of nonfinancial disclosures and thus report beyond the bottom line. Given that, companies currently struggle with increased pressure from internal and external stakeholders to report on their social and environmental performance.

Over time a number of frameworks and standards have been proposed in relation to how to report on nonfinancial information. At present, they may provide a collection of ideas about how to supplement financial reports, but not all of those models succeeded in becoming generally accepted. Ligteringen and Zadek (2004) report that there are more than 300 global corporate standards, which encourage corporate responsibility reporting regarding environmental and social issues. The study of Marimon et al. (2012) provides a brief classification of corporate responsibility standards highlighting UN Global Compact Principles, OECD Guidelines for Multinational Enterprises, GRI, ISO 26000, AA1000, ISO 14001 and SA88000. Despite the pursuit of different initiatives encouraging CSR disclosure, a need for an internationally recognized and generally accepted framework to achieve the uniformity in CSR reporting remains.

Global Reporting Initiative (GRI) guidelines, developed in 1997, deserve a particular attention as they are today the most widely used (Ballou et al., 2006; 
Roca and Searcy, 2012). Marimon et al. (2012) states that GRI reports currently approach forty percent of all corporate responsibility reports worldwide and the highest number of certifications in the GRI has been detected in Europe (Welford, 2004; Rowe, 2006). Outtes-Wanderley et al. (2008) stressed that the reason behind this could be that developed nations such as Eurozone countries implement practical actions that stimulate CSR awareness, e.g. the fact that in March 2000, the European Council set the strategic goal of becoming the most competitive and dynamic knowledge-based economy in the world (European Council, 2000). Hence, in a knowledge-based economy, the element of nonfinancial information, particularly of human capital, is increasingly important.

To measure the extent of human capital online reporting, an index based on combining different sustainability frameworks (including GRI and other available and relevant CSR frameworks) such as: AA 1000, Caux Round Table Principles, DOMINI 400, EIRIS, EMAS, Ethical Trading Initiative, FTSE4 Good Index, Global Compact, GRI, ISO 9000 and 14001, SA8000 was developed. Based on which it consists of specific and measurable indicators (considering a reasonable number of indicators based on the principle of materiality).

Human capital is an intangible asset with a strong potential to create value, which is not shown on the balance sheet (Eccles and Krzus, 2010). In triple bottom line it belongs to the category of social indicators and is considered one of the most important resources as the competitiveness of a company is predominantly dependent on this particular factor, especially in the knowledge-based economy.

If a company wants to survive in a dynamic and changing environment, it has to develop abilities that are difficult for competitors to copy. For this reason, increased attention is currently being turned to human capital, which can represent a unique source of competitive edge. Effective human capital processes lead to a company's ability to produce goods and services more effectively than competitors. Therefore, information about company`s human capital indicators are being well appreciated by investors and other stakeholders as they help them to obtain a clearer picture about a company`s real value.

In order to keep pace with the rapidly evolving business environment companies are forced to adapt quickly and consider the most effective ways of reporting. Reporting via Internet enables timely information disclosure, it is cost saving, and 
it allows more interactive displays than traditional print media. These attributes caused that corporate reporting using the Internet has been embraced by so many companies worldwide. According to Jones et al. (1998) and Koreto (1997) it is a valuable tool which increases corporate transparency and accountability on environmental and social issues. Therefore, for the purposes of our study we analyzed the human capital disclosure in sustainability or annual report available on the company`s website.

\section{THEORETICAL BACKGROUND}

The framework of legitimacy theory has been used as a background for several studies related to CSR disclosure (Branco and Rodriguez, 2006; Deegan, 2002; Gray et al., 1995; Kim, 2017). In compliance with this theory, a company tries to appear legitimate to its stakeholders by endorsing generally accepted ways of doing business as a response to societal pressures. That is why historical, cultural, social and environmental forces shape generally accepted ways of doing business. Based upon these institutional influences, internal as well as external, many companies apply similar practices. Matten and Moon (2008) stressed that a firm's explicit CSR reporting that is not mandated by a law can be regarded as the search for moral legitimacy that is granted by stakeholders. Thus, in the context of company disclosure, the end result is that managers observe other companies reporting practices and reflexively apply them in their own companies (Aerts et al., 2006).

According to Hoffman (1999), companies within a sector and a region share many stakeholders who are interested in their practices. Thus, they must legitimize their activities - including human capital practices - to them. This approach suggests that companies within the same sector and region create an institutional context in which they benchmark each other in order to gain acceptance and relevance and legitimize their practices. Hence, the reporting practices of a company appear to be related to industry and country-specific effects. According to Gray et al. (1995), these findings are consistent with the legitimacy theory.

Over the years, a number of proxies were used to test legitimacy theory. Haniffa and Cooke (2005) found that the size of the company and ethnic representation are positively related to CSR disclosure. Ratanajongkol et al. (2006) conducted a study noting a positive relationship between the industry and the extent of CSR 
disclosure. The result of this study was also supported by other authors such as Amran and Devi (2008) and Gray et al. (1995). Campbell (2000) stated that a company provides non-financial information such as those related to environmental or social issues, as a strategy to manage its legitimacy by showing that its activity is in keeping with social norms and beliefs and that it is acting in an environmentally responsible way. Although most of the analyzed companies operate worldwide, the region where they are headquartered might influence the way they approach the reporting on human capital, given that American and European institutional backgrounds are remarkably different. Similarly, dividing companies into critical and non-critical sector, our study suggests a sector effect on the extent to which companies report on human capital due to the legitimacy theory which implies that companies belonging to a particular sector category tend to have similar reporting practices.

\section{OBJECTIVES AND RESEARCH QUESTIONS}

Sustainable reporting deals predominantly with environmental, social and governance indicators, also called ESG metrics. Particular indicators used by a company may vary according to the framework that was applied. In this study we mainly focus on human capital reporting. The main aim is to examine the extent to which German and American companies report online on human capital and to define the current trends of reporting on social indicators. The other objective is to identify the factors that influence ways of reporting. To analyze the human capital online reporting practices of German and American companies, an index consisting of specific and measurable indicators was applied. A detailed summary of how the index was calculated is provided in the methodology part.

The next objective of our study was to determine the factors that influence the extent of reporting on human capital indicators. This led us to formulate the research questions discussed below. The dependent variable is the human capital reporting index. Further, we identified the group of factors that might have an influence on the reporting practices of the companies; thus, we indicated the independent variables used for this study as follows: the company size, the country where the company is headquartered and the industry in which it operates. All tested variables are well-grounded by the legitimacy theory and previously used in the studies related to CSR disclosure. 


\subsection{Research Questions}

In general, the majority of the literature on empirical studies indicated company size as one of the most frequently used variables to determine the level of information disclosure. As concluded by several studies (Depoers, 2000; Larrán and Giner, 2002, Rodríguez-Ariza et al., 2014), large companies are more likely to disclose information than small ones are. It can therefore be assumed that if a company reaches a certain size, this tends to influence its reporting practices due to the greater need for legitimacy. This leads us to the first research question:

$R Q_{1}$ Is the extent of online reporting on human capital indicators positively associated with the company size?

The size of the company was measured by the number of employees.

Clearly, the region in which the company operates plays a significant role in its disclosure practices, due to various factors, including historical, cultural and social matters. According to Fifka and Drable (2012) several studies have noted differences in the extent and style of reporting across different countries. A study conducted by Goloba and Barlett (2006) comparing the reporting practices between two countries from different continents supports this argument and points out that various differences may appear in reporting practices, as well as in the level of disclosure on nonfinancial information, due to regional factors. Fifka and Drable (2012) conducted research examining the sustainability reports of the 100 largest companies in the United Kingdom and Finland, pointing out that both countries are highly developed countries in North-Western Europe, but their cultural and socio-economic systems differ. His study shows that the cultural and socio-economic environment has an impact on the extent of reporting. Culture influence on the extent of disclosure is well-grounded by the legitimacy theory stressing that region where the company is headquartered creates an institutional context in which companies benchmark each other and often adopt similar practices in order to gain acceptance and legitimize their activities. Thus, culture represents a crucial dimension of sustainability disclosure practices, and there is a growing number of researchers who include cultural background as one of the key variables in their studies (Cormier and Magnan, 2007; Crossland, 2007; Waddock, 2008; Outtes-Wanderley et al., 2008; Young and Marais, 2012). 
In our study, we compared the companies headquartered in the USA and Germany, both highly developed countries, however, with different cultural and socio-economic systems. Although the regulatory bodies like security market regulators in the United States have been encouraging companies to extend their non-financial disclosure, there is no doubt that due to the EU regulation on nonfinancial disclosure from $29^{\text {th }}$ of September 2014 and the new Directive concerning the CSR disclosure, the large European countries are under stronger scrutiny. Therefore, we might assume that due to the cultural and socio-economic differences of both regions their human reporting practices might differ too.

Accordingly, our second research question was formulated:

$R Q_{2}$ Does the extent of reporting on human capital indicators depend on the country where the company is headquartered?

Many studies found a link between industry where the company operates and its CSR reporting practices (Azim et al., 2009; Frynas, 2010; Outtes-Wanderlay et al., 2008). Azim et al. (2009) and Ogrizek (2002) claimed that financial services represent the leading sector in CSR reporting. The study of Frynas (2010) stressed the high rank in terms of CSR reporting by the oil and gas sector. While OuttesWanderlay et al. (2008) concluded that the energy sector, banking and telecommunications report the most on sustainability issues.

Following the rich literature of empirical studies, industry type was used as one of the most frequent variables to explain disclosure of information (Bazley et al., 1985; Wagenhofer, 1990). Therefore, companies belonging to the same sector might show similar information disclosure practices. For this study, a classification based upon the Global Industry Classification Standards distinguishing 11 sectors was applied (GICS) with a further classification into critical and non-critical sector. Our approach is also supported by legitimacy theory which implies that companies belonging to a particular sector category tend to have similar reporting practices. This leads us to our third research question:

$R Q_{3}$ Does the level of disclosure on human capital depend on the sector that the company operates in? 


\section{METHODOLOGY}

For this study, the sample of 60 companies listed in the DAX 30 and in the Fortune 500 (top 30 companies ranked by total revenues for their respective fiscal years). This sample was chosen because of the influential role that these companies play in the business world. Thus, studying the social reporting practices of these companies can offer an interesting insight into the current online reporting practices and trends relating to human capital.

All the official corporate web pages were examined in order to obtain an actual annual report including a chapter on ESG reporting, which is generally considered a common practice, or a sustainable report as a separate document. The particular report was then explored and content analysis based on the created framework was conducted. The data were collected in February 2017.

To explore the extent to which German and American companies report on human capital, a content analysis of annual reports or separated sustainability reports on the official companies' websites has been made. The reports were analyzed with regard to the nature of human capital disclosures. To measure the extent of online reporting on human capital indicators, we developed an index that considers items of information directly related to the content of human capital. To construct the index, different CSR frameworks which includes human capital indicators were used (GRI, AA 1000, Caux Round Table Principles, DOMINI 400, EIRIS, EMAS, Ethical Trading Initiative, FTSE4 Good Index, Global Compact, GRI, ISO 9000 and 14001, SA8000) following the approach of Spanish Accounting Association (AECA) which created the Integrated Scorecard recognized by International XBRL, which is the first CSR framework in XBRL format following the principles of IIRC. The index was calculated on a scale from 0 to 9 , depending on the information which was or was not included in the sustainability report.

Human capital indicators consider the following aspects:

1. Employees. Number of employees with a contract at year end

2. Gender diversity of employees. Number of women with a contract at the year end

3. Gender diversity of top employees. Number of women at the top level of the entity 
4. Job stability. Number of employees with a permanent contract

5. Accidents and diseases at workplace. Number of lost days

6. Absenteeism. Number of lost days

7. Employee turnover. Total number of employees leaving employment during the reporting period

8. Seniority. Number of years of permanence of all employees

9. Employees' training. Number of training hours for the year

Authors adopted a manual collection process starting with identifying official corporate websites, where they looked for either annual report or separated sustainability report. As content analysis is a standard method for systematically comparing the content of communications it has been applied to our study as well. Thus, all reports available online were analyzed and based on the presence of the information about particular human capital indicator one point was assigned for each indicator. This way, an index (on scale 0-9) was assigned to each company representing the extent of online human capital reporting.

\section{FINDINGS}

\subsection{Descriptive Statistics}

Of the 60 companies, no one had reported on all nine social indicators and there were only three which had reported on eight indicators, all of them from Germany. Table 1 provides descriptive statistics information. It was also found that the distribution of the human capital reporting index is not normal; based upon that, non-parametric statistics were used later.

According to the results of this study, the average human capital reporting index by both German and American companies is 4.15. The highest reporting activity was detected on indicators such as number of employees $(100 \%$ of the companies), gender diversity of employees (73\% of the companies) and gender diversity of top employees on the management board (73\% of the companies). In addition, among the surveyed sample, companies also tended to report quite extensively on employee training provided by the company (45\% of the companies) and employee turnover (43\% of the companies). 


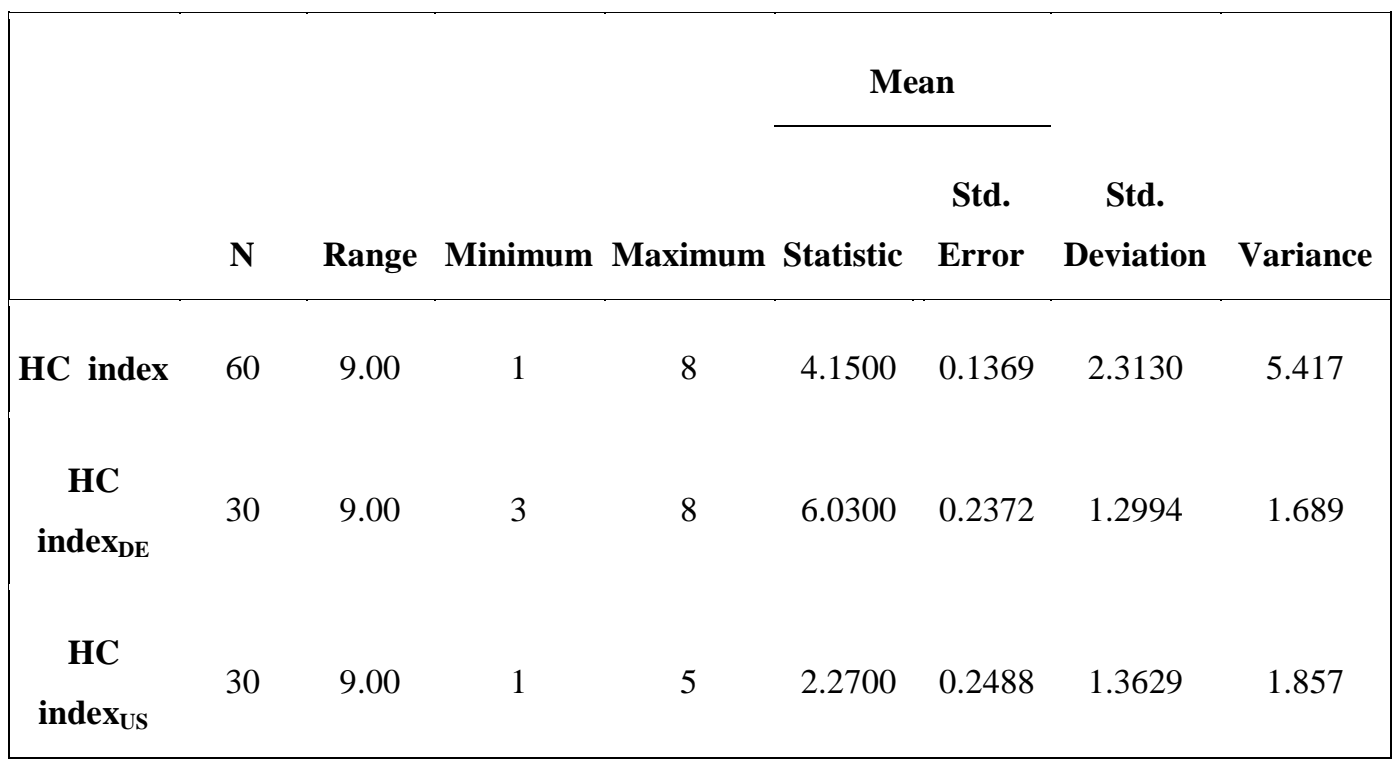

Table 1. Descriptive Statistics

The number of companies reporting on particular human capital indicators is provided in Table 2 .

\begin{tabular}{|lcc|}
\hline \multicolumn{1}{|c}{ Indicator } & No. of companies & $\%$ \\
\hline Employees & 60 & 100.00 \\
Gender diversity of employees & 44 & 73.33 \\
Gender diversity of top employees & 44 & 73.33 \\
Employees training & 27 & 45.00 \\
Employee turnover & 26 & 43.33 \\
Job stability & 18 & 30.00 \\
Accidents and diseases at workplace & 15 & 25.00 \\
Seniority & 12 & 20.00 \\
Absenteeism & 3 & 5.00 \\
\hline
\end{tabular}

Table 2. Companies Reporting on Human Capital Indicators 


\subsection{Human capital reporting by industry}

The first two columns of Table 3 provide an overview of the sector categories, according to the GICS and according to critical/non-critical separation. The third and fourth columns include information about the average index calculated for each sector.

\begin{tabular}{|l|l|r|}
\hline & \multicolumn{2}{|c|}{ Human capital reporting by industry } \\
\hline Sector (GICS) & Critical/Non-critical & Average Index per sector \\
\hline Materials & Non-critical & 7.00 \\
\hline Utilities & Critical & 6.50 \\
\hline Real Estate & Non-critical & 6.00 \\
\hline Consumer Discretionary & Non-critical & 5.11 \\
\hline Financials & Non-critical & 4.35 \\
\hline Telecommunication Services & Non-critical & 4.25 \\
\hline Consumer Staples & Non-critical & 3.80 \\
\hline Health Care & Non-critical & 3.54 \\
\hline Information Technology & Non-critical & 3.38 \\
\hline Industrials & Critical & 3.13 \\
\hline Energy & Critical & 2.00 \\
\hline & & $\mathbf{3 . 6 8}$ \\
\hline Average index critical sector & & \\
\hline Average index non-critical & & \\
\hline & & \\
\hline
\end{tabular}

Table 3. Human Capital Reporting by Industry and Country 
As can be seen in Table 3, the highest average index was normally detected in the non-critical sectors (except of Utilities) such as Materials, Real Estate, and Consumer Discretionary. Lower scoring in the human capital reporting had companies operating in critical sectors: Industrials, and Energy.

\subsection{Human capital reporting by country}

\begin{tabular}{|c|c|}
\hline Country & Average Index per Country \\
\hline Germany & 6.03 \\
\hline USA & 2.27 \\
\hline
\end{tabular}

Table 4. Human Capital Reporting by Country

The study examined the extent to which German and American companies report online on human capital. Table 4 also provides a comparison of average index per country showing a significant difference in the extent of reporting on nine human capital indicators. The average index value for Germany is 6.03 while for the USA only 2.27 .

\subsection{Research Questions Testing}

Based on the set of research questions the impact of three independent variables on the extent of reporting on human capital indicators was analyzed. To answer these research questions, a Pearson correlation was applied to measure the correlation between the dependent variable (human capital reporting index) and company size (number of employees). To measure the median variances between the dependent variable - human capital reporting index and binary variables such as region ( $0=$ German companies, $1=$ American companies) the Mann-Whitney $\mathrm{U}$ test was applied. Another Mann-Whitney test was applied to test the relationship between the sector $(0=$ non-critical, $1=$ critical $)$ and the dependent variable HCRI. The results are presented in Table 5. 


\begin{tabular}{|c|c|c|c|c|}
\hline $\begin{array}{c}\text { Dependent } \\
\text { variable }\end{array}$ & $\begin{array}{c}\text { Independent } \\
\text { variable }\end{array}$ & Method & Value & $\begin{array}{l}\text { Asymp. Sig. } \\
\text { (2-tailed) }\end{array}$ \\
\hline \multirow[t]{3}{*}{ HCRI } & $\mathrm{RQ}_{1}$ Company size & Pearson & -0.083 & 0.528 \\
\hline & $\mathrm{RQ}_{2}$ Country & $\begin{array}{l}\text { Mann- } \\
\text { Whitney }\end{array}$ & U test value: 30.000 & 0.000 \\
\hline & $\mathrm{RQ}_{3}$ Sector & $\begin{array}{l}\text { Mann- } \\
\text { Whitney }\end{array}$ & $\begin{array}{l}\text { U test value: } \\
247.000\end{array}$ & 0.022 \\
\hline
\end{tabular}

Table 5. Determinants of Human Capital Reporting Index

This implies that there is no correlation between the company size and the extent of human capital reporting as the significance level was $0.528\left(\mathrm{RQ}_{1}\right)$. Conducting the Mann-Whitney $U$ test there a relationship was found between the extent of reporting on human capital indicators and the region where the company is headquartered. Thus, German companies tend to have more developed human capital disclosure than American companies. According to the Mann-Whitney test, $\mathrm{RQ}_{3}$ was confirmed as well, which implies that the sector in which the company operates may have an influence on the extent of $\mathrm{HC}$ reporting.

Based on the non-parametrical tests conducted in our study, the obtained results confirmed two of three proposed research questions. Regarding the country where the company is headquartered, and the industry in which it operates, statistically significant relationships were found thus it could be concluded that these results support the relationships suggested in previous studies mentioned in this work and they are also consistent with the legitimacy theory, as these two factors represent institutional influences based on which a company tries to appear legitimate to its stakeholders. Based on the size of the company measured by the number of employees no significant correlation has been found. 


\section{DISCUSSION AND CONCLUSIONS}

Many companies from around the world have come to realize the significant role of reporting on nonfinancial information to supplement financial reporting. They either include a section dealing with the information which is not shown on the balance sheet in their corporate annual reports, or publish a separated sustainability report, usually available online. They realized the importance of meeting stakeholder expectations as a condition of sustainability in order to achieve overall strategic business objectives.

The aim of this paper was to analyze the extent to which the extent to which German and American companies report online on human capital indicators, and the factors that can influence it. Findings show an average disclosure index of 4.15, but there is a huge difference between German and American companies. While an average disclosure index is case of German companies 6.03, the average index value for American companies is only 2.27. Considering the scale 0-9 and an enormous gap between Germany and the USA, we came to the conclusion that Europe`s leading position in sustainability reporting in undeniable, and on the other side, online disclosure on human capital in the USA is still scarce and in its early stages.

Regarding the indicators, the highest reporting activity was detected on indicators such as number of employees (100\%), gender diversity of employees (73\%) and gender diversity of top employees on the management board (73\%). In addition, among the surveyed sample, the companies also tended to report quite extensively on employee training provided by the company (45\%) and employee turnover $(43 \%)$. On the other hand, the items with the lowest reporting rates were absenteeism (5\%) seniority (20\%), accidents and diseases at workplace $(25 \%)$ and job stability (30\%).

The empirical evidence obtained from this study implies that American companies do not report very extensively on their social performance if we compare them with the German ones. This may stem from the failure to see the competitive advantage of such a disclosure or a lack of stakeholders' interests. However, different studies suggest that CSR reporting have the potential to improve a company`s image, influence customers` purchase intentions, shareholders investment decisions, and also has an impact on the selection of B2B 'partners (Bartels et al., 2008; Clacher and Hagendorff, 2012). 
The other objective was to identify the factors that influence ways of reporting. To identify the factors that influence a company's human capital reporting practices, a set of research questions was established and tested. The considered variables were: company size, country where the company is headquartered and sector in which the company operates.

We found out that the latter two (country and sector) have an impact on the extent of online reporting on human capital indicators.

Based on the legitimacy theory, the prior research shows that a company's reporting practices are dependent upon its industry and country of residence (Fifka and Drable, 2012; Goloba and Barlett, 2006; Gray and Bebbington, 2000). The results of our study are consistent with this previous research, as both the industry as well as the country were confirmed as having an influence on human capital reporting.

More specifically, a relationship was found between the extent of reporting on human capital and the sector in which the company operates. The results show that companies operating in the non-critical sectors (except of Utilities) such as Materials, Real Estate and Consumer Discretionary are more likely to report on those indicators. Thus, our results are in compliance with previous studies (Azim et al., 2009; Outtes-Wanderlay et al., 2008; Frynas, 2010) and principles of the legitimacy theory.

The size of the company was frequently used to explain the extent of disclosure (Gallego et al., 2009), however, according to the results which emerged from this study, based on the size of the company measured by the number of employees no significant correlation has been found.

\subsection{Conclusions}

The findings showing that the industry in which the company operates and country where the company is headquartered have an impact on the extent of human capital reporting complement the legitimacy theory views on corporate reporting practices.

There is a trend for companies being pressed by their internal and external stakeholders to measure and report on their social and environmental performance. This pressure leads companies worldwide to publish this 
information, either in annual financial reports or in voluntary sustainability reports available online. Thus, online sustainability reporting might be perceived as a tool for companies to present themselves as good citizens and legitimate their activity. Moreover, taking advantage of media richness the Internet offers, such a disclosure might be even more powerful and reach out a wider audience. In scope of sustainability reporting, the category - human capital belongs to the intangible assets with the potential to create value and enhance a competitive edge for a company. Therefore mapping the area of human capital online disclosure deserves the attention of both academics and professionals.

\section{Practical implications}

The study offers an overview of current online human capital reporting practices in Germany and in the USA. Among the practical implications of this study is highlighting the scarcity of online reporting on human capital indicators by American companies due to the lack of regulations at the national levels in this area, which might be the reason why companies are less willing to report on them in comparison with e. g. environmental indicators. Our results open up new avenues for future research as we are the first to analyze the extent of human capital reporting on the international level focusing on German and American companies.

\section{Limitations}

Our first objective was to analyze the extent to which German and American companies report on human capital using widely reported indicators. For a more complete and clear overview of the extent of reporting and current reporting practices of German and American companies, a broader set of indicators might be used. Additionally, an interesting line of research could also be to map the evolution of the extent of HC online reporting in Germany and in the USA as well as including also medium and small sized companies into the sample. 


\section{REFERENCES}

AERTS W.; CORMIER, D.; MAGNAN, M. (2006): Intra-industry imitation in corporate environmental reporting: An international perspective, Journal of Accounting and Public Policy, Vol. 25, No. 3: 299-331. http://dx.doi.org /10.1016/j.jaccpu bpol.2006.03.004

ALVARADO-HERRERA, A.; BIGNE, E.; ALDAS-MANZANO, J.; CURASPEREZ, R. (2017): A Scale for Measuring Consumer Perceptions of Corporate Social Responsibility Following the Sustainable Development Paradigm, Journal of Business Ethics, Vol. 140, No. 2: 243-262. http://dx.doi.org /10.1007/s10551015-2654-9

AMERICAN INSTITUTE OF CERTIFIED PUBLIC ACCOUNTANTS (1994): Improving business reporting: a customer focus, New York.

AMRAN, A.; DEVI, S.S. (2008): The impact of government and foreign affiliate influence on corporate social reporting: The case of Malaysia, Managerial Auditing Journal, Vol. 23, No. 4: 386-404. https://doi.org/10.1108/ 02686900810864327

ARVIDSSON, S. (2010): Communication of corporate social responsibility: A study of the views of management teams in large companies, Journal of Business Ethics, Vol. 96, No. 3: 339-354. https://doi.org/10.1007/s10551-0100469-2

AZIM, M.I.; AHMED, S.; ISLAM, M. (2009): Corporate social reporting practice: evidence from listed companies in Bangladesh, Journal of Asia-Pacific Business, Vol. 10, No. 2: 130-145. https://doi.org/10.1080/10599230902885556

BALlOU, B.; HEITGER, D.; LANDES, C. (2006): The Future of Corporate Sustainability Reporting: A Rapidly Growing Assurance Opportunity, http://referensi.dosen.narotama.ac.id/files/2012/01/The-Future-of-CorporateSustainability.pdf

BARTELS, W.; IANSEN-ROGERS, J.; KUSZEWSKI, J. (2008): Count me in The readers' take on sustainability reporting, Amstelveen, KPMG. 
BAZLEY, M.; BROWN, P.; IZAN, H.Y. (1985): An analysis of lease disclosures by Australian companies, Abacus, Vol. 21, No. 1: 44-63. https://doi.org/ 10.1111/j.1467-6281.1985.tb00111.x

CAMPBELL, D.J. (2000): Legitimacy theory or managerial reality construction? Corporate social disclosure in Marks and Spencer Plc annual corporate reports, 1969-1997, Accounting Forum, Vol. 24, No. 1: 80-100. https://doi.org/ $10.1111 / 1467-6303.00030$

CHO, C.H.; PHILLIPS, J.R.; HAGEMAN, A.M; PATTEN, D.M. (2009): Media richness, user trust, and perception of corporate social responsibility: An experimental investigation of visual web site disclosures, Accounting, Auditing \& Accountability Journal, Vol. 22, No. 6: 933-952. https://doi.org/10.1108/ 09513570910980481

CLACHER, I.; HAGENDORFF, J. (2012): Do Announcements about Corporate Social Responsibility Create or Destroy Shareholder Wealth? Evidence from the UK, Journal of Business Ethics, Vol. 106, No. 3: 253-266. https://doi.org/ 10.1007/s10551-011-1004-9

CORMIER, D.; LEDOUX, M.J.; MAGNAN, M. (2009): The use of Web sites as a disclosure platform for corporate performance, International Journal of Accounting Information Systems, Vol. 10, No. 1: 1-24. https://doi.org/ 10.1016/j.accinf.2008.04.002

CORMIER, D.; MAGNAN, M. (2007): The revisited contribution of environmental reporting to investors' valuation of a firm's earnings: An international perspective, Ecological Economics, Vol. 32, No. 3-4: 613-626. https://doi.org/10.1016/j.ecolecon.2006.07.030

CROSSLAND, C. (2007), "National institutions and managerial discretion: A taxonomy of 24 countries", paper presented at the annual meeting of Academy of Management, August, Philadeplphia, PA.

DAVISON, J. (2007): Photographs and accountability: cracking the codes of an NGO, Accounting, Auditing \& Accountability Journal, Vol. 20, No. 1: 133-158. https://doi.org/10.1108/09513570710731236 
DEPOERS, F. (2000): A cost-benefit study of voluntary disclosure: Some empirical evidence from French listed companies, European Accounting Review, Vol. 9: 245-263.

EBNSC (2000): European Campaign on CSR 2000-2005, A New Age for Partnership Between Business, Governments and Civil Society, http://www.ebnsc.org

ECCLES, R.; ARMBRESTER, K. (2011): Integrated reporting in the cloud. Sustainability: bringing life to your business, IESE insight, Issue 8.

ECCLES, R.; KRZUS, M. (2010): One report. Integrated reporting for a sustainable strategy, New York: John Wiley \& Sons.

EUROPEAN COUNCIL (2000): Presidency conclusions, Lisbon European Council, http://wwwue.eu.int/ueDocs/cms_Data/docs/pressData/en/ec/00100r1.en0.htm

FIFKA, M.; DRABLE, M. (2012): Focus and standardization of sustainability reporting - a comparative study of the United Kingdom and Finland, Business Strategy and the Environment, Vol. 21, No. 7: 455-474. https://doi.org/ $10.1002 / \mathrm{bse} .1730$

FINANCIAL ACCOUNTING STANDARDS BOARD (2001): Improving business reporting: insights into enhancing voluntary disclosures. Stanford.

FRÍAS-ACEITUNO, J.V.; CONCEICAO-MARQUES, M.; LÁZARORODRÍGUEZ, A. (2013): Sustainability Disclosure: Does it adapt to society`s expectations? Revista de Contabilidad, Vol. 16, No. 2: 147-158.

FRYNAS, J.G. (2010): Corporate social responsibility and societal governance: lessons from transparency in the oil and gas sector, Journal of Business Ethics, Vol. 93: 163-179. https://doi.org/10.1007/s10551-010-0559-1

GALLEGO, I.; GARCÍA, I.; RODRÍGUEZ, L. (2009): Universities' web sites: disclosure practices and the revelation of financial information, The International Journal of Digital Accounting Research, Vol. 9, pp. 153-192. https://doi.org/ 10.4192/1577-8517-v9_6 
GEORGALLIS, P. (2016): The Link Between Social Movements and Corporate Social Initiatives: Toward a Multi-level Theory, Journal of Business Ethics, Vol. 142, No. 4: 735-751. https://doi.org/10.1007/s10551-016-3111-0

GICS (2017): Global Industry Classification Standard, https://www.msci.com/gic

GOLOBA, U.; BARTLETT, J. (2006): Communicating about corporate social responsibility: A comparative study of CSR reporting in Australia and Slovenia, http://www.sciencedirect.com/science/article/pii/S0363811106001433

GRAY, R.H.; BEBBINGTON, K.J. (2000): Accounting for the environment, 2nd ed. Sage, London.

GRAY, R.; KOUHY, R.; LAVERS, S. (1995): Corporate social and environmental disclosure, Accounting, Auditing and Accountability Journal, Vol. 8, No. 2: 44-77. https://doi.org/10.1108/09513579510146996

GRI (2010): GRI Sustainability Reporting Statistics, https://www.globalreporting. org/resourcelibrary/GRI-Reporting-Stats-2010.pdf

HANIFFA, R.M.; COOKE, T.E. (2005): The impact of culture and governance on corporate social reporting, Journal of Accounting and Public Policy, Vol. 24, No. 5: 391-392. https://doi.org/10.1016/j.jaccpubpol.2005.06.001

HARTMAN, L.P., RUBIN, R.S.; DHANDA, K.K. (2007): The communication of corporate social responsibility: United States and European Union multinational corporations, Journal of Business Ethics, Vol. 74, No. 4: 373-389. https://doi.org/10.1007/s10551-007-9513-2

HOFFMAN, A.J. (1999): Institutional evolution and change: Environmentalism and the US chemical industry, Academy of Management Journal, Vol. 42, No. 4: 351-371. https://doi.org/10.2307/257008

IR (2011): Discussion paper, "Towards integrated reporting', Communicating value in the $21^{\text {st }}$ century", http://www.theiirc.org/discussion-paper/

JOHNSTON, P. (2001): Corporate Responsibility in Employment Standards in a Global Knowledge Economy. In Zadek, S., Hojensgard, N. and Raynard, P. (eds.), 
Perspectives on the New Economy of Corporate Citizenship (43-47), The Copenhagen Centre.

JONES, K.; ALABASTER, T.; WALTON, J. (1998): Virtual environments for environmental Reporting, Greener Management International, Vol. 21: 121-37.

KIM, S. (2017): The Process Model of Corporate Social Responsibility (CSR) Communication: CSR Communication and its Relationship with Consumers' CSR Knowledge, Trust, and Corporate Reputation Perception, Journal of Business Ethics, 1-17, https://doi.org/10.1007/s10551-017-3433-6.

KOLK, A. (2007): Sustainability, accountability and corporate governance: exploring multinationals' reporting practices, Business Strategy and the Environment, Vol. 17, No.1: 1-15. https://doi.org/10.1002/bse.511

KORETO, R.J. (1997): When the bottom line is online, Journal of Accountancy, Vol. 183, No. 3: 63-5.

KPMG (2011): International Survey of Corporate Responsibility Reporting 2011, http://www.kpmg.com/global/en/issuesandinsights/articlespublications/pressreleases/pages/corporate-responsibility-reporting.aspx

LARRÁN, M.; GINER, B. (2002): The use of the internet for corporate reporting by Spanish companies, The International Journal of Digital Accounting Research, Vol. 2, No. 1: 53-82. https://doi.org/10.4192/1577-8517-v2_3

LEE, W.E.; HAGEMAN, A.E. (2016): Talk the Talk or Walk the Walk? An Examination of Sustainability Accounting Implementation, Journal of Business Ethics, 1-15. https://doi.org/10.1007/s10551-016-3282-8

LIGTERINGEN, E.; ZADEK, S. (2004): The future of corporate responsibility standards, Accounting Forum, Vol. 4: 6-17.

LONGO, M.; MURA, M.; BONOLI, A. (2005): Corporate social responsibility and corporate performance: The case of Italian SMEs, Corporate Governance, Vol. 5, No.4: 28-42. https://doi.org/10.1108/14720700510616578

MARIMON, F.; ALONSO-ALMEIDA, M.; RIDRÍGUEZ, M. (2012): The worldwide diffusion of the global reporting initiative: what is the point? Journal 
of Cleaner Production, Vol. 33: 132-144. https://doi.org/10.1016/j.jclepro.2012. 04.017

OGRIZEK, M. (2002): The effect of corporate social responsibility on the branding of financial services, Journal of Financial Services Marketing, Vol. 6, No. 3: 215-228. https://doi.org/10.1057/palgrave.fsm.4770053

\section{ORGANIZATION FOR ECONOMIC COOPERATION AND DEVELOPMENT} (2006): Intellectual assets and value creation: Implications for corporate reporting, December, 11.

OUTTES-WANDERLEY, L.; SOARES, L.; LUCIAN, R.; FARACHE, F.; DE SOUSA FILHO MILTON, J. (2008): CSR information disclosure on the web: a context-based approach analyzing the influence of country of origin and industry sector, Journal of Business Ethics, Vol. 82: 369-378. https://doi.org/ $10.1007 / \mathrm{s} 10551-008-9892-\mathrm{z}$

RAO, K.; TILT, C. (2016): Board Composition and Corporate Social Responsibility: The Role of Diversity, Gender, Strategy and Decision Making, Journal of Business Ethics, Vol. 138, No. 2: 327-347. https://doi.org/ 10.1007/s10551-015-2613-5

RATANAJONGKOL, S.; DAVEY, H.; LOW, M. (2006): Corporate social reporting in Thailand: The news is all good and increasing, Qualitative Research in Accounting and Management, Vol. 3, No. 1: 67-83. https://doi.org/ 10.1108/11766090610659751

ROCA, L.C.; SEARCY, C. (2012): An analysis of indicators disclosed in corporate sustainability reports, Journal of Cleaner Production, Vol. 20, No. 1: 103-118. https://doi.org/10.1016/j.jclepro.2011.08.002

RODRÍGUEZ-ARIZA, L.; FRÍAS-ACEITUNO, J.V.; GARCÍA-RUBIO, R. (2014): The board of directors and the sustainability report, Revista de Contabilidad, Vol. 17, No. 1: 5-16.

ROWE, M. (2006): Reputation relationships and risk: a CSR primer for ethics officers, Business and Society Review, Vol. 111, No. 4: 441-455. https://doi.org/10.1111/j.1467-8594.2006.00281.x 
SHEEHY, B. (2015): Defining CSR: Problems and Solutions, Journal of Business Ethics, Vol. 131, No. 3: 625-648. https://doi.org/10.1007/s10551-014-2281-x

SKOLOUDIS, A.; EVANGELINOS, K.I. (2009): Sustainability reporting in Greece: Are we there yet? Environmental Quality Management, Vol. 19, No. 1: 43-59. https://doi.org/10.1002/tqem.20235

STEVENSON, W.B.; STECKLER, E.L. (2015): Rhetorical Strategies for Claims of Corporate Sustainability, The Journal of Corporate Citizenship, Vol. 2015, No. 59: 148-167. https://doi.org/10.9774/gleaf.4700.2015.se.00010

WADDOCK, S. (2008): Building a new institutional infrastructure for corporate responsibility, Academy of Management Perspectives, Vol. 22, No. 3: 87-108. https://doi.org/10.5465/amp.2008.34587997

WAGENHOFER, A. (1990): The demand for disclosure and actual disclosure by firms, paper presented at the 13th Annual Congress of the European Accounting Association, Budapest.

WARREN, S. (2002): Show me how it feels to work here: using photography to research organizational aesthetics, Ephemera, Vol. 2, No. 3: 224-45.

WEBER, O. (2008): The relation between the GRI indicators and the financial performance of firms, Progress in Industrial Ecology, Vol. 5, No. 3: 236-254. https://doi.org/10.1504/pie.2008.019127

WELFORD, R. (2005): Corporate social responsibility in Europe, North America and Asia, The Journal of Corporate Citizenship, Vol. 2005, No. 17: 33-52. https://doi.org/10.9774/gleaf.4700.2005.sp.00007

YOUNG, S.; MARAIS, M. (2012): A Multi-level Perspective of CSR Reporting: The Implications of National Institutions and Industry Risk Characteristics, Corporate Governance: An International Review, Vol. 20, No. 5: 432-450. https://doi.org/10.1111/j.1467-8683.2012.00926.x 